Article

\title{
Does Curcumin Have a Role in the Interaction between Gut Microbiota and Schistosoma mansoni in Mice?
}

\author{
Assmaa Anter ${ }^{1, \dagger}$, Mohamed Abd El-Ghany ${ }^{2,+} \mathbb{0}$, Marwa Abou El Dahab ${ }^{3}$ and Noha Mahana ${ }^{1, *}$ \\ 1 Zoology Department, Faculty of Science, Cairo University, Giza 12613, Egypt; assmaa99.aa@gmail.com \\ 2 Botany and Microbiology Department, Faculty of Science, Cairo University, Giza 12613, Egypt; \\ mabdelghany@sci.cu.edu.eg \\ 3 Zoology Department, Faculty of Science, Ain Shams University, Cairo 11566, Egypt; \\ m_aboueldahab_78@yahoo.com \\ * Correspondence: nmahana@sci.cu.edu.eg or nohamahana@gmail.com; Tel.: +20-2-3567-6708 \\ + These two authors contributed equally to the research work.
}

Received: 12 July 2020; Accepted: 19 August 2020; Published: 19 September 2020

\begin{abstract}
There is strong correlation between changes in abundance of specific bacterial species and several diseases including schistosomiasis. Several studies have described therapeutic effects of curcumin (CUR) which may arise from its regulative effects on intestinal microbiota. Thus, we examined the impact of CUR on the diversity of intestinal microbiota with/without infection by Schistosoma mansoni cercariae for 56 days. Enterobacteriaceae was dominating in a naive and S. mansoni infected mice group without CUR treatment, the most predominant species was Escherichia coli with relative density $($ R.D $\%)=80.66 \%$ and the least one was Pseudomonas sp. $(0.52 \%)$. The influence of CUR on murine microbiota composition was examined one week after oral administration of high (40) and low (20 mg/kg b.w.) CUR doses were administered three times, with two day intervals. CUR induced high variation in the Enterobacteriaceae family, characterized by a significant $(p<0.001)$ reduction in E. coli and asignificant $(p<0.001)$ increase in Pseudomonas sp. in both naïve and $S$. mansoni-infected mice, compared to untreated mice, in a dose-dependent manner. Additionally, our study showed the effects of high CUR doses on S. mansoni infection immunological and parasitological parameters. These data support CUR's ability to promote Pseudomonas sp. known to produce schistosomicidal toxins and offset the sequelae of murine schistosomiasis.
\end{abstract}

Keywords: Schistosoma mansoni; curcumin; mouse gut microbiota; Pseudomonas aeruginosa; immune responses; parasitological parameters

\section{Introduction}

A large number of parasitic worms and eggs reside in close interaction with gut capillaries, mucosa, and lumen, among these blood flukes of the genus Schistosoma (Digenean flatworms, trematodes) [1]. The major Schistosoma causative agents of schistosomiasis include S. mansoni, S. haematobium, and S. japonicum. Owing to morbidity and mortality, human schistosomiasis is the most problematic of the human helminthiases [2]. Schistosomiasis or snail fever, one of the major neglected diseases, causes hundreds of millions of infections in several countries of the Middle East, Sub-Saharan Africa, Latin America, and Asia, threatening the economy worldwide [3,4]. About 393 million people in Sub-Saharan Africa are at risk of infection, from which 54 million are infected [5]. Blood fluke S. mansoni cercariae released from freshwater Biomphalaria snails penetrate human skin and change into schistosomula, which migrate via the blood and lymphatic system to the lung. Thereafter, juvenile worms travel to the venous system of the liver where they mature. After about four weeks, the adult worms migrate into the mesenteries of 
the intestine, pair up, and become fertile producing hundreds to thousands of eggs per day upon six weeks [6]. Eggs traverse the intestinal wall into intestinal lumen and exit with the stool.

Numerous eggs are retained within the distal vasculature of the intestine and sinusoids of the liver and drift to various tissues, namely the liver. Vigorous immune granulomatous responses to the egg-derived antigens lead to liver fibrosis, intestinal bleeding, and portal hypertension [7], indicating that eggs are responsible for the pathology of schistosomiasis [8]. The immune responses to worm antigens (during the first weeks of infection) are predominantly of the type 1 [9]. Upon egg laying, immune responses rapidly shift to the type 2 axis, characterized by preponderance of interleukin (IL)-13, IL-5, IL-4 $[7,10]$. This shift of immune responses may be mediated directly or indirectly by modifications in the composition of the intestinal commensal microbiota [11], and promotes mutual benefit, or leads to the eradication of one partner, and affects egg number and viability [12]. In mice treated with antibiotics simultaneously with infection with S. mansoni, the host microbiota was found to contribute to triggeringhelminth-specific immune responses [13].

Microbiota such as prokaryotes (bacteria, archaea), viruses, and unicellular eukaryotes reside in the human body, and have a role in individual health. The most colonized organ is the gastrointestinal tract where the colon contains more than $70 \%$ of all the microbes in the human body [14]. The major factors that influence the microbiota number and distribution are genetics, diet, antibiotics and the presence of pathogens [15]. Direct contribution of gut microbiota in disease pathogenesis was elucidated by Carding et al. [16]. The association between bacterial and parasitic infection may influence symptom severity, reduce treatment efficacy, or contribute to other symptomatic presentations. The bacterial microbiota also provide protection from colonization by pathogenic microbes, either directly, by producing secondary metabolites such as toxins, antibiotics, enzymes, etc. or competing for nutrients and space, or indirectly, by promoting intestinal barrier function [17].

Treatment and control of schistosomiasis usually depend on only one drug, praziquantel (PZQ) [18]. However, the existence of resistant strains and negative side effects associated with PZQ make alternate treatment strategies attractive $[19,20]$. Curcumin (CUR) is a major effective component of Curcuma longa Linn. (turmeric) rhizomes. It has several pharmacological activities and therapeutic potential against many diseases [21,22]. Antibacterial, antiparasitic, and antifungal activity of CUR was evaluated in vitro, in animal, and in some human studies $[23,24]$. Despite the low bioavailability and rapid metabolism of CUR $[25,26]$, it is still used as drug in several studies and this may be explained by the interplay between CUR and gut microbiota [27]. The data obtained on the impact of CUR on gut microbiota is still incomplete, although several animal studies showed its efficacy on gut microbial diversity [28].

The current study aims to investigate the impact of infection with S. mansoni and CUR administration on outbred mice gut microbiota, in addition to the impact of simultaneous S. mansoni infection and CUR treatment on mice gut microbiota number and diversity, the immunological responses to the worm antigens, parasite worm burden, parasite egg counts, and hatchability. This study might provide a new sight for schistosomiasis novel therapy.

\section{Results}

\subsection{Impact of S. Mansoni Infection on the Composition of Gut Microbiota}

Female healthy Swiss albino CD-1 mice ofsix weeks old, were randomly distributed into two groups of four mice each, $S$. mansoni infected and entirely naïve groups. The mice infection was percutaneous with 100 Egyptian strains of $S$. mansoni cercariae (SBSP/TBRI) per mouse. Eight weeks later, both naïve and infected (eight weeks post infection, pi) mice were examined for the composition of gut microbiota.

Mice were dissected and the small intestinal contents (mucus and feces) were collected, diluted, inoculated on a selective, differential medium, and examined by using traditional biochemical methods for identification of recovered microbial species of gut microbiota. In naïve and $S$. mansoni infected 
mice, Enterobacteriaceae was the most predominant family of Gram-negative bacteria, which can be recovered on a selective and differential medium, represented by the following order Escherichia coli (Figure 1), Enterobacter sp., Serratia sp., Klebsiella sp., and Pseudomonas sp. (Figure 2). The next family in abundance was Staphylococcaceae including Staphylococci sp. followed by Enterococci sp., which belongs to Enterococcaceae family, and Bacillaceae was the least represented family in count exemplified by Bacillus sp. (Figure 2). The most dominant species was E. coli with R.D $\%=80.66 \%$ (Figure 1A) and the least one was Pseudomonas sp. (0.52\%) (Figure 2). By comparison with naïve mice, S. mansoni infection induced a significant $(p<0.001)$ increase in R.D \% of Klebsiella sp. $(0.11 \%)$ and Staphylococci sp. $(0.12 \%)$ and a decrease in R.D\% of the remaining species. On the other hand, insignificant alterations in the growth of Candida sp. was observed in S. mansoni infected mice compared to naïvemice (Figure 2).

A

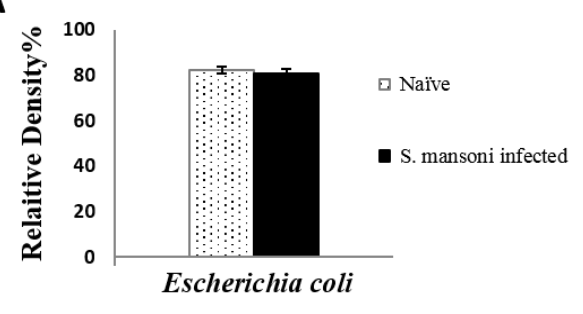

B

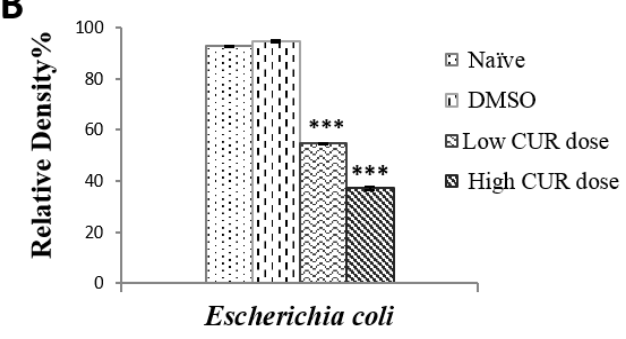

C

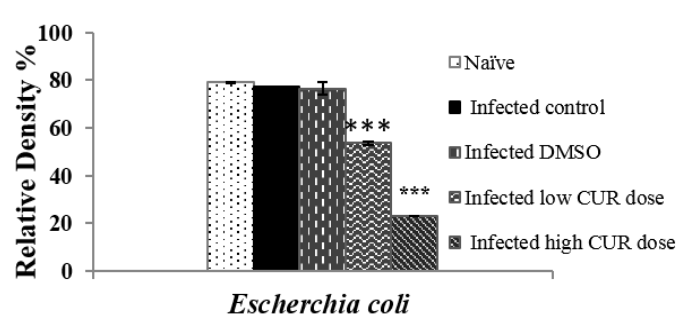

Figure 1. Relative density percentage of Escherichia coli isolated from (A) naïve and Schistosoma mansoni infected; (B) naïve, dimethyl sulfoxide (DMSO), low ( $20 \mathrm{mg} / \mathrm{kg}$ b.w.) and high ( $40 \mathrm{mg} / \mathrm{kg}$ b.w.) doses of curcumin (CUR); (C) infected, infected DMSO, infected mice groups treated with low and high doses of CUR. Bars are means of four individual mice with $( \pm)$ standard deviation (SD) around the mean. ${ }^{* * *}$ Extremely significant $(p<0.001)$. 


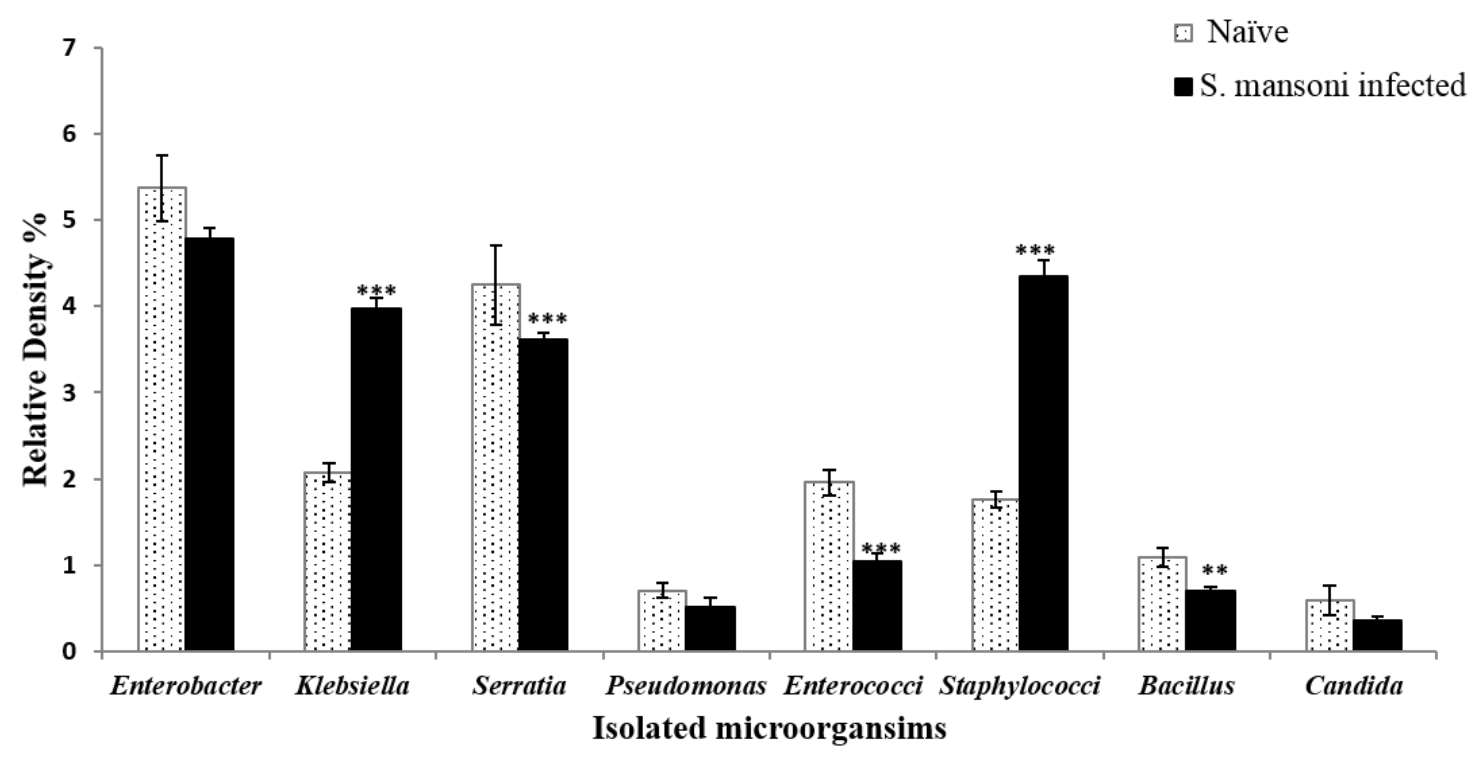

Figure 2. Relative density percentage of microbial isolates, isolated from naïve and Schistosoma mansoni infected mice groups. Bars are means of 4 individual mice with $( \pm)$ standard deviation (SD) around the mean. ${ }^{* *}$ Highly significant $(p<0.01),{ }^{* * *}$ Extremely significant $(p<0.001)$.

\subsection{Influence of Curcumin on the Composition of Mice Gut Microbiota}

A total of 20 female, six-week-old CD-1 mice were divided into four groups (five mice/each). The first group was left intact, and the others were orally given $1.0 \mathrm{~mL} / \mathrm{mouse}$ of RPMI medium supplemented with 1\% DMSO containing 0 (DMSO controls), 20 (low), and 40 (high) $\mathrm{mg} / \mathrm{kg}$ b.w. CUR doses. Treatment was given orally three times, with two day intervals. These mice were assayed for the effect of CUR on the intestinal microbiota one week after the last oral administration.

Administration of DMSO (solvent) did not show any significant differences in the R.D\% of microbiota compared to the naïve mice (Figure 3). Mice that received high and low doses of CUR showed a significant difference in microbial diversity of mice gut microbiota. Pseudomonas sp. was significantly $(p<0.001)$ the most expressed genus in the Enterobacteriaceae family recovered after high and low CUR doses with R.D $\%=62.64 \%$ and $14.82 \%$, respectively, when compared with DMSO and naïve control groups that showed R.D $\%=0.024 \%$ and $0.03 \%$, respectively (Figure 3). Meanwhile, the dominance of $E$. coli was diminished by the administration of the high and low doses of CUR (22.34\% and 56.02\%, respectively) in comparison with naïve and DMSO controls with R.D\% (97.95\% and $98.01 \%$, respectively) (Figure 1B). Furthermore, a significant $(p<0.000)$ inhibition of growth of Candida $s p$. in mice administered with low and high CUR doses was detected compared to naïve and DMSO control mice groups (Figure 3). On the other hand, insignificant alterations in Staphylococcaceae, Enterococcaceae, and Bacillaceae families were observed in CUR-administered groups compared to controls (Figure 3). 


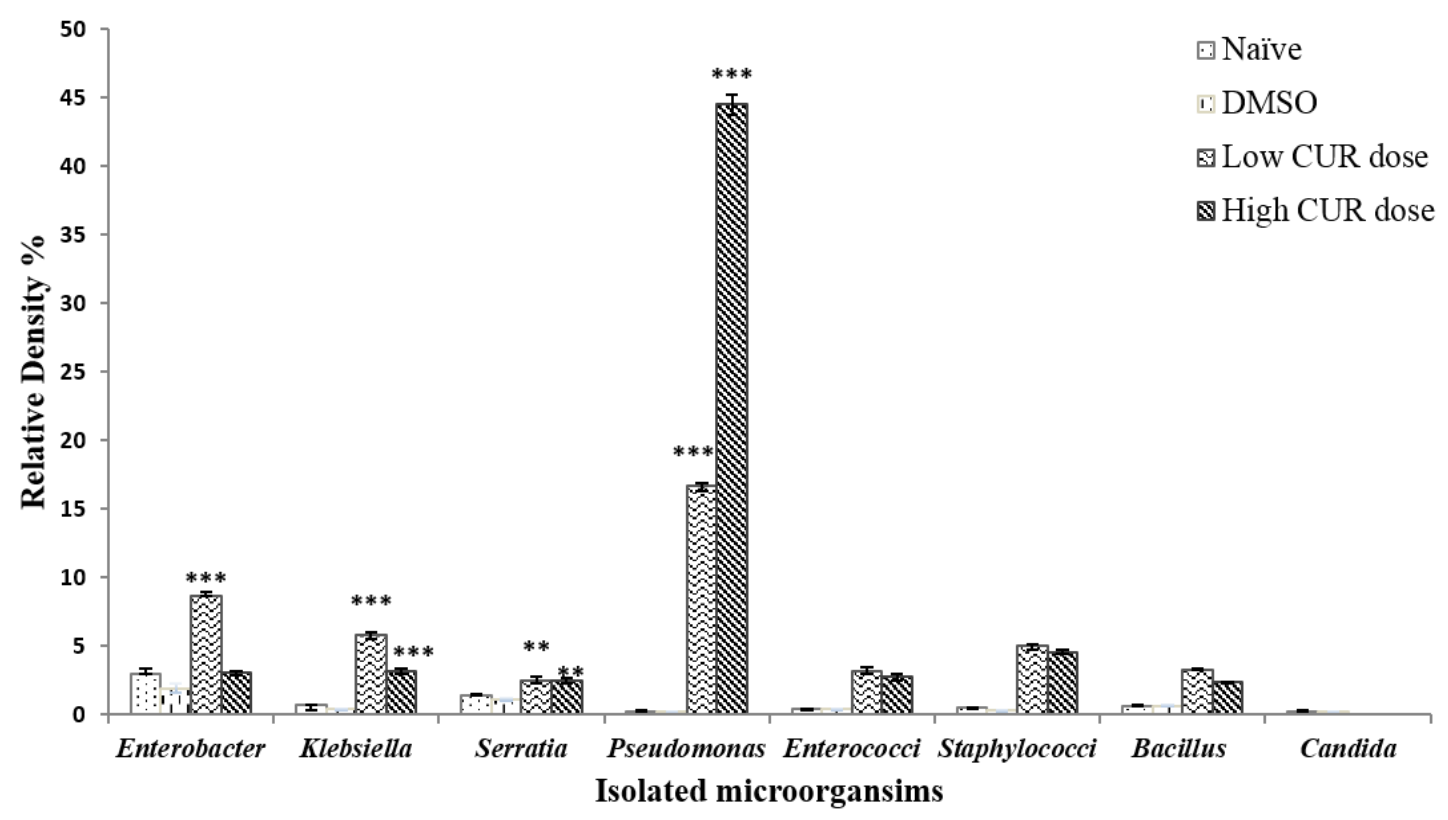

Figure 3. Relative density percentage of microbial isolates, isolated from naïve, dimethyl sulfoxide (DMSO), low (20 mg/kg b.w.), and high (40 mg/kg b.w.) doses of curcumin (CUR) mice groups. Bars are means of five individual mice with $( \pm)$ standard deviation (SD) around the mean. ${ }^{* *}$ Highly significant $(p<0.01),{ }^{* * *}$ Extremely significant $(p<0.001)$.

\subsection{Schistosomes, CUR, and Gut Microbiota Interactions}

\subsubsection{Effects on the Microbiota}

It was found that the composition of mice intestinal microbiota infected with $S$. mansoni was not significantly affected by the administration of DMSO (Figure 4). S. mansoni infected mice treated with high $(40 \mathrm{mg} / \mathrm{kg}$ b.w.) and low $(20 \mathrm{mg} / \mathrm{kg}$ b.w.) doses of CUR induced a great variation in the diversity of genera of intestinal microbiota. Pseudomonas $s p$. (Enterobacteriaceae family) was significantly $(p<0.0001)$ the most dominant species with R.D $\%=22.59 \%$ and $57.19 \%$, respectively, in the gut microbiota of mice treated with low and high CUR doses in comparison with the R.D\% of naïve, untreated, infected, and DMSO infected control groups $(0.62 \%, 0.61 \%$, and $0.81 \%$, respectively) (Figure 4). While E. coli counts and R.D\% were decreased at a high dose $(40 \mathrm{mg} / \mathrm{kg}$ b.w.) of CUR treated, infected mice to $22.96 \%$, although it was the most dominant species in the Enterobacteriaceae family of gut-microbiota that appears in naïve, untreated infected, DMSO infected control groups and mice treated with a low dose $(20 \mathrm{mg} / \mathrm{kg}$ b.w.) of CUR had an R.D $\%=79.17 \%, 77.3 \%, 76.5 \%$, and $53.58 \%$, respectively (Figure 1C). 


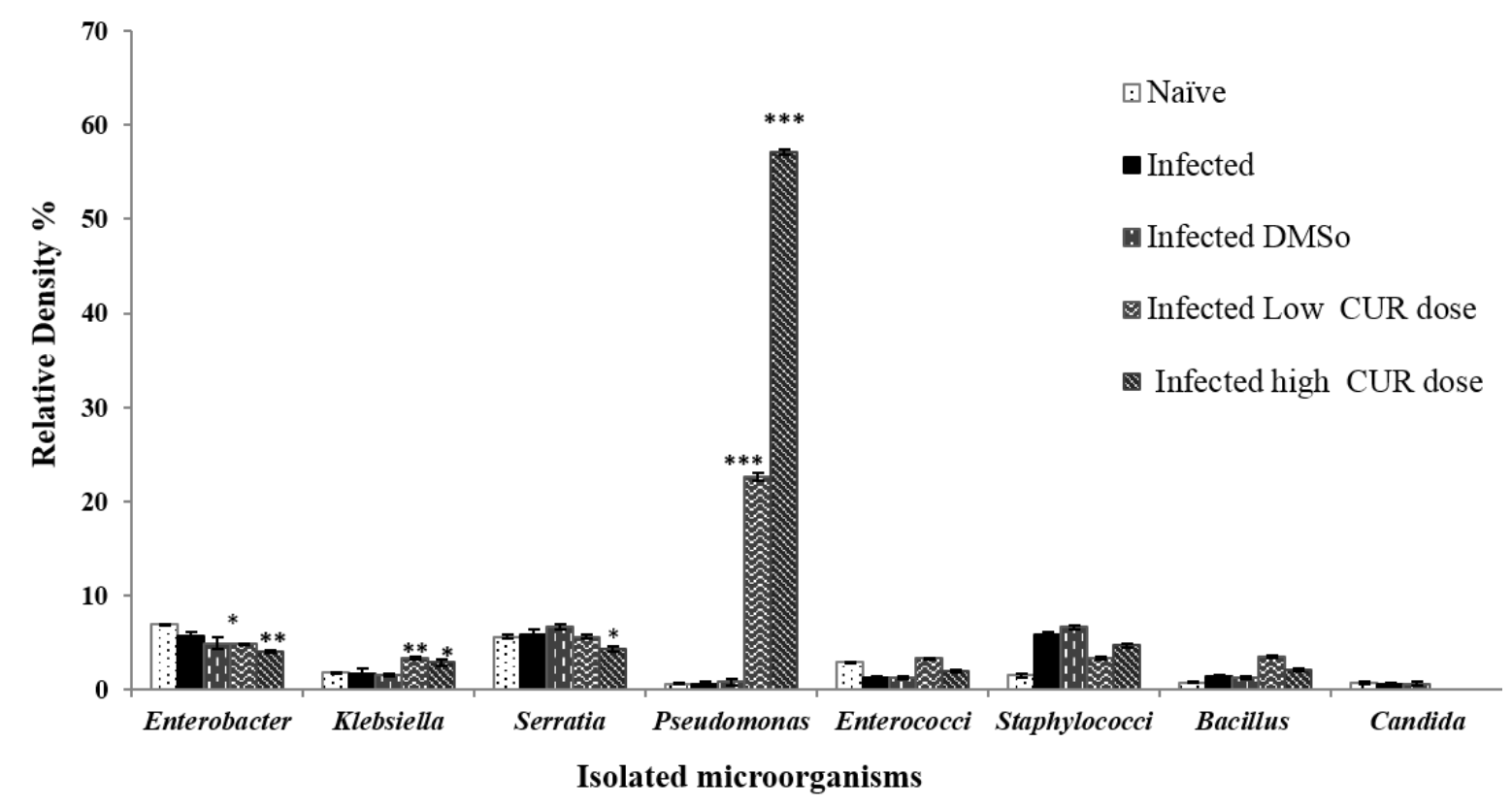

Figure 4. Relative density percentage of microbial isolates, from naïve, infected, infected dimethyl sulfoxide (DMSO), infected mice groups treated with low $(20 \mathrm{mg} / \mathrm{kg} \mathrm{b.w.)}$ and high ( $40 \mathrm{mg} / \mathrm{kg}$ b.w.) doses of CUR. Bars are means of 4-5 individual mice with ( \pm ) standard deviation (SD) around the mean. * Significant $(p<0.05),{ }^{* *}$ Highly significant $(p<0.01),{ }^{* * *}$ Extremely significant $(p<0.001)$.

Additionally, a significant inhibition of growth of Candida sp. and an insignificant alteration in Staphylococcaceae, Enterococcaceae, and Bacillaceae families, was observed in both CUR treated S. mansoni infected groups compared to naïve and infected control ones (Figure 4).

\subsubsection{Effects on Immune Responses against Schistosome Egg Antigens}

Antibody Levels. Naïve and infected mice treated with CUR at 0, 20, or $40 \mathrm{mg} / \mathrm{kg}$ b.w. were investigated for serum levels of anti-rLAP IgG antibodies. Compared to naïve mice all S. mansoni infected mice displayed significant serum antibody binding to the antigen to a titer of 6400 , with mice treated with the high CUR dose constantly showing higher $(p<0.01)$ absorbance values than mice of the other groups (Figure 5). Antibody isotype analysis of sera obtained from individual mice revealed that antibodies binding to rLAP were of IgM and IgG1 isotypes up to a titer of 1:500 and 1:50, respectively, while little (IgG2b and $\operatorname{IgA}$ ) or no (IgG2a and IgE) other antibody isotypes were detected (Table 1). 


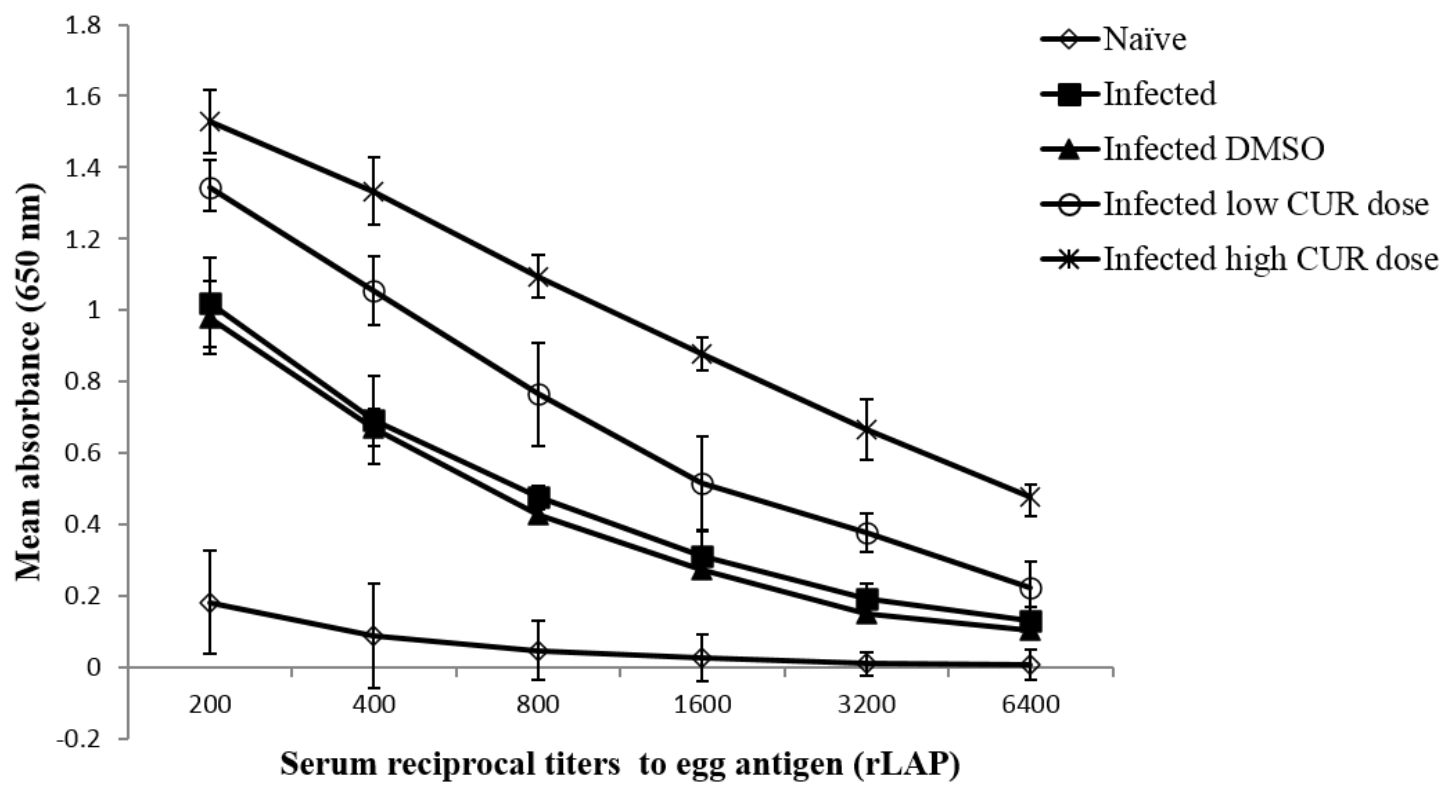

Figure 5. Effect of curcumin (CUR) administration on total serum IgG antibody titers response to recombinant leucine aminopeptidase (rLAP). The data are representative of two independent experiments. Serum of five naïve and Schistosoma mansoni infected mice treated with CUR at 0 (DMSO), low (20 mg/kg b.w.), and high (40 mg/kg b.w.) doses were tested for antibody titer to rLAP. Each point represents mean ELISA absorbance $(650 \mathrm{~nm})$ of five mice tested in duplicate, and vertical bars denote the standard error (SE) around the mean.

Table 1. Effect of curcumin administration on serum antibody isotypes response to recombinant leucine aminopeptidase (rLAP).

\begin{tabular}{ccccccc}
\hline \multirow{2}{*}{ Groups } & \multicolumn{7}{c}{ Mean \pm SD } \\
\cline { 2 - 7 } & IgM & IgG1 & IgG2a & IgG2b & IgA & IgE \\
\hline Naïve & $0.089 \pm 0.010$ & $0.032 \pm 0.017$ & $0.066 \pm 0.033$ & $0.069 \pm 0.008$ & $0.037 \pm 0.045$ & $0.004 \pm 0.002$ \\
(Cut off) & $(0.109)$ & $(0.066)$ & $(0.132)$ & $(0.085)$ & $(0.127)$ & $(0.008)$ \\
I & $0.284 \pm 0.038^{*}$ & $0.180 \pm 0.024^{*}$ & $0.063 \pm 0.018$ & $0.070 \pm 0.017$ & $0.045 \pm 0.013$ & $0.006 \pm 0.005$ \\
ID & $0.219 \pm 0.067^{*}$ & $0.112 \pm 0.076^{*}$ & $0.049 \pm 0.036$ & $0.138 \pm 0.045^{*}$ & $0.143 \pm 0.019 *$ & $0.007 \pm 0.003$ \\
IL & $0.289 \pm 0.101^{*}$ & $0.189 \pm 0.056^{*}$ & $0.041 \pm 0.021$ & $0.053 \pm 0.034$ & $0.056 \pm 0.025$ & $0.007 \pm 0.003$ \\
IH & $0.274 \pm 0.075^{*}$ & $0.598 \pm 0.130^{*}$ & $0.036 \pm 0.033$ & $0.062 \pm 0.020$ & $0.120 \pm 0.040$ & $0.007 \pm 0.003$ \\
\hline
\end{tabular}

The data are representative of two independent experiments whereby sera obtained from five naïve mice and Schistosoma mansoni infected untreated (I) and treated mice trice with curcumin at 0 (ID), low (20 mg/kg b.w.) (IL), and high (40 mg/kg b.w.) (IH) doses six weeks after infection were tested for antibody isotypes response to rLAP, a major egg antigen. The serum samples were diluted 1:500 (for IgM, IgG2a) and 1:50 (for IgG1, IgG2b, IgA, IgE). * Significant $(p<0.05)$.

Cytokine Results. Eight-week infection with S. mansoni failed to significantly alter the levels of circulating IFN- $\gamma$ or IL-4; treatment of infected mice with low and high CUR doses resulted in a highly significant $(p<0.001)$ increase in circulating IL-4 levels (Figure 6). 


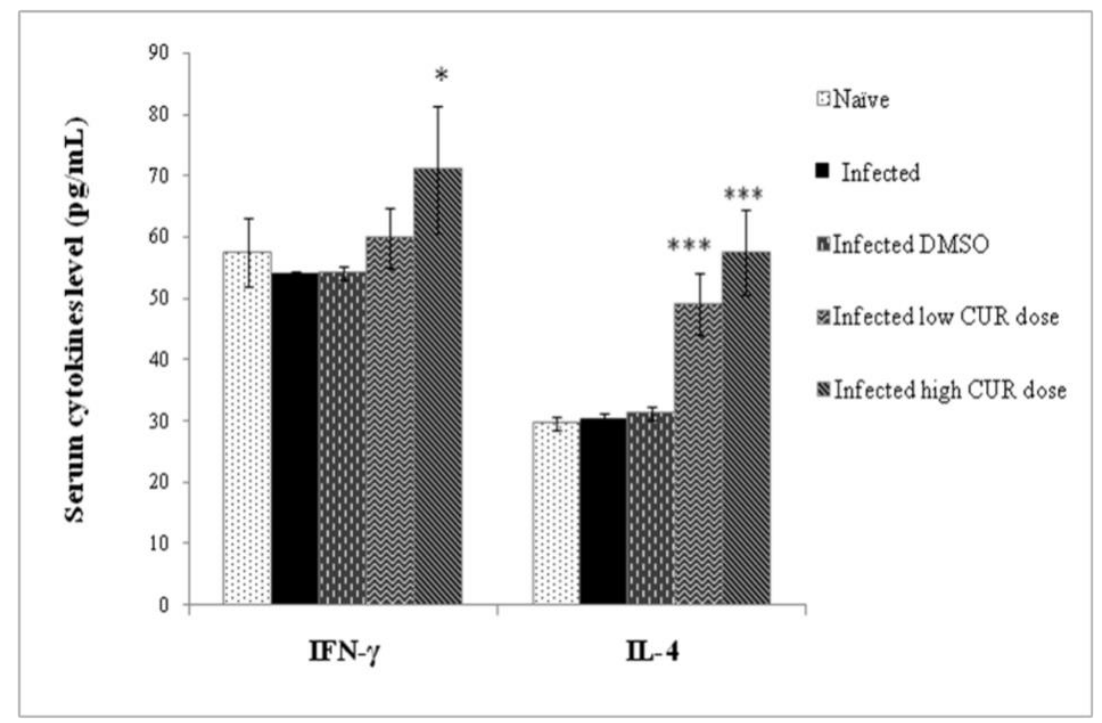

Figure 6. Effect of curcumin (CUR) administration on serum cytokine levels of Schistosoma mansoni infected CD-1 mice assessed eight weeks post infection. The data are representative of two independent experiments. Serum offive naïve and $S$. mansoni infected mice treated with CUR at 0 (DMSO), low $(20 \mathrm{mg} / \mathrm{kg} \mathrm{b.w.)}$, and high (40 mg/kg b.w.) doses were tested for circulating cytokine levels. Bars are means of replicate measurements of five individual mice with $( \pm)$ standard deviation (SD) around the mean. * Significant $(p<0.01),{ }^{* * *}$ Extremely significant $(p<0.001)$.

\subsubsection{Effects on Parasitological Parameters}

Worm Burden. In the present investigation, treatment of $S$. mansoni infected mice with a high dose of CUR $(40 \mathrm{mg} / \mathrm{kg} \mathrm{B.W})$ caused a significant $(p<0.001)$ reduction in male, female, and total worm burdens by $65.9 \%, 61.4 \%$, and $64 \%$, respectively. Otherwise, the changes occurring in DMSO infected control and low CUR dose $(20 \mathrm{mg} / \mathrm{kg}$ b.w.) treated groups were statistically not significant $(p \geq 0.05)$ compared to the infected untreated mice group, as shown in Table 2. 
Table 2. Effect of curcumin administration on parasitological parameters of S. mansoni infected mice.

\begin{tabular}{|c|c|c|c|c|}
\hline Parameter Counts & $\mathbf{I}$ & ID & IL & IH \\
\hline \multicolumn{5}{|l|}{ Total worm burden } \\
\hline Mean \pm SD & $43.34 \pm 8.44$ & $42.0 \pm 2.65$ & $42.0 \pm 15.25$ & $15.60 \pm 10.01$ \\
\hline$p$ value & & 0.81 & 0.9 & $0.007^{* * *}$ \\
\hline Reduction (\%) & & $3.10 \%$ & $3.10 \%$ & $64.00 \%$ \\
\hline \multicolumn{5}{|l|}{ Male worm burden } \\
\hline Mean \pm SD & $24.67 \pm 3.95$ & $23.0 \pm 3.61$ & $26.25 \pm 11.15$ & $8.40 \pm 5.90$ \\
\hline$p$ value & & 0.62 & 0.83 & $0.006^{* * *}$ \\
\hline Reduction (\%) & & $6.70 \%$ & & $65.90 \%$ \\
\hline \multicolumn{5}{|c|}{ Female worm burden } \\
\hline Mean \pm SD & $18.67 \pm 4.46$ & $19.0 \pm 4.58$ & $15.75 \pm 5.12$ & $7.20 \pm 4.87$ \\
\hline$p$ value & & 0.93 & 0.47 & $0.005^{* * *}$ \\
\hline Reduction (\%) & & $77.70 \%$ & $15.60 \%$ & $61.40 \%$ \\
\hline \multicolumn{5}{|l|}{ Liver egg counts } \\
\hline Mean \pm SD & $40,333 \pm 17,616$ & $48,333.3 \pm 14,433.76$ & $63,750 \pm 17,100.2$ & $48,333 \pm 22,317$ \\
\hline$p$ value & & 0.58 & 0.14 & 0.61 \\
\hline Reduction (\%) & & & - & - \\
\hline \multicolumn{5}{|l|}{ Intestine egg counts } \\
\hline Mean \pm SD & $68,500 \pm 2121.3$ & $52,750 \pm 30,774.7$ & $53,500 \pm 33,426.5$ & $39,666 \pm 14,982.2$ \\
\hline$p$ value & & 0.53 & 0.58 & $0.042^{* * *}$ \\
\hline Reduction (\%) & & & $21.90 \%$ & $42.10 \%$ \\
\hline \multicolumn{5}{|l|}{$\%$ Immature ova } \\
\hline Mean \pm SD & $33.70 \pm 7.42$ & $35.48 \pm 12.5$ & $24.9 \pm 6.1$ & $20.86 \pm 5.22$ \\
\hline$p$ value & & 0.84 & 0.19 & $0.02^{* * *}$ \\
\hline Reduction (\%) & & & $27.30 \%$ & $39.40 \%$ \\
\hline \multicolumn{5}{|l|}{$\%$ Mature ova } \\
\hline Mean \pm SD & $58.38 \pm 8.85$ & $57.57 \pm 11.03$ & $62.97 \pm 5.2$ & $50.25 \pm 11.5$ \\
\hline$p$ value & & 0.92 & 0.48 & 0.32 \\
\hline Reduction (\%) & & $1.70 \%$ & & $13.70 \%$ \\
\hline \multicolumn{5}{|l|}{ \% Dead ova } \\
\hline Mean \pm SD & $7.83 \pm 4.51$ & $6.96 \pm 3.0$ & $12.13 \pm 4.6$ & $28.9 \pm 10.9$ \\
\hline$p$ value & & 0.7 & 0.22 & $0.02^{* * *}$ \\
\hline Increase (\%) & & & $34.90 \%$ & $72.90 \%$ \\
\hline
\end{tabular}

The data are typical of two independent experiments. Schistosoma mansoni infected untreated (I) and treated mice with curcumin (CUR) at 0/DMSO (ID), low (20 mg/kg b.w.) (IL), and high ( $40 \mathrm{mg} / \mathrm{kg}$ b.w.) (IH) doses six weeks after infection with $150 \pm 50$ cercariae and assessed (five per group) for parasitological parameters eight weeks post infection. Differences between CUR-treated and control mice were assessed for significance using Mann-Whitney test. Reduction or Increase $\%=$ mean number in untreated control mice-mean number in CUR-treated mice/mean number in untreated control mice $\times 100 .{ }^{* * *}$ Extremely significant $(p<0.001)$.

Parasite Egg Counts. Treatment of $S$. mansoni infected mice with high $(40 \mathrm{mg} / \mathrm{kg})$ CUR dose caused a significant $(p<0.05,42.1 \%)$ reduction in eggs per gram tissue of small intestine but not significantly $(p \geq 0.05)$ in liver egg load. On the other hand, the DMSO infected control group and mice treated with alow $(20 \mathrm{mg} / \mathrm{kg}$ b.w.) CUR dose did not show any significant reduction in eggs per gram tissue of either the small intestine or liver compared to the infected control group (Table 2).

Egg Oogram. The study of the oogram pattern for enumeration of the various egg types is an easy and reliable method of evaluating the therapeutic values of anti-schistosomal drugs. In the current study, treatment with a high CUR dose $(40 \mathrm{mg} / \mathrm{kg}$ b.w.) elicited a significant increase $(p<0.05)$ in both immature and dead ova with (39.4 and $72.9 \%$, respectively), while a non-significant value $(p \geq 0.05)$ with $13.7 \%$ was obtained from mature ones. Likewise, there were no statistically significant $(p \geq 0.05)$ changes in the percentages of dead, immature or mature eggs in the DMSO infected control group and mice treated with a low CUR dose (20 mg/kg b.w.) compared to the infected control group (Table 2). 
Eggs' Hatchability. The present study showed thateggs from the small intestine of mice treated with high $(40 \mathrm{mg} / \mathrm{kg}$ b.w.) and low $(20 \mathrm{mg} / \mathrm{kg}$ b.w.) CUR doses released a significantly $(p<0.0001$ and $p<0.05$, respectively) higher percentage of hatched eggs before exposure to deionized water compared to control and infected DMSO groups (Figure 7). After $1 \mathrm{~h}$ incubation with deionized water under direct illumination to induce egg hatching, no miracidia were seen in the supernatant of eggs of mice treated with CUR (40 and $20 \mathrm{mg} / \mathrm{kg}$ b.w.).

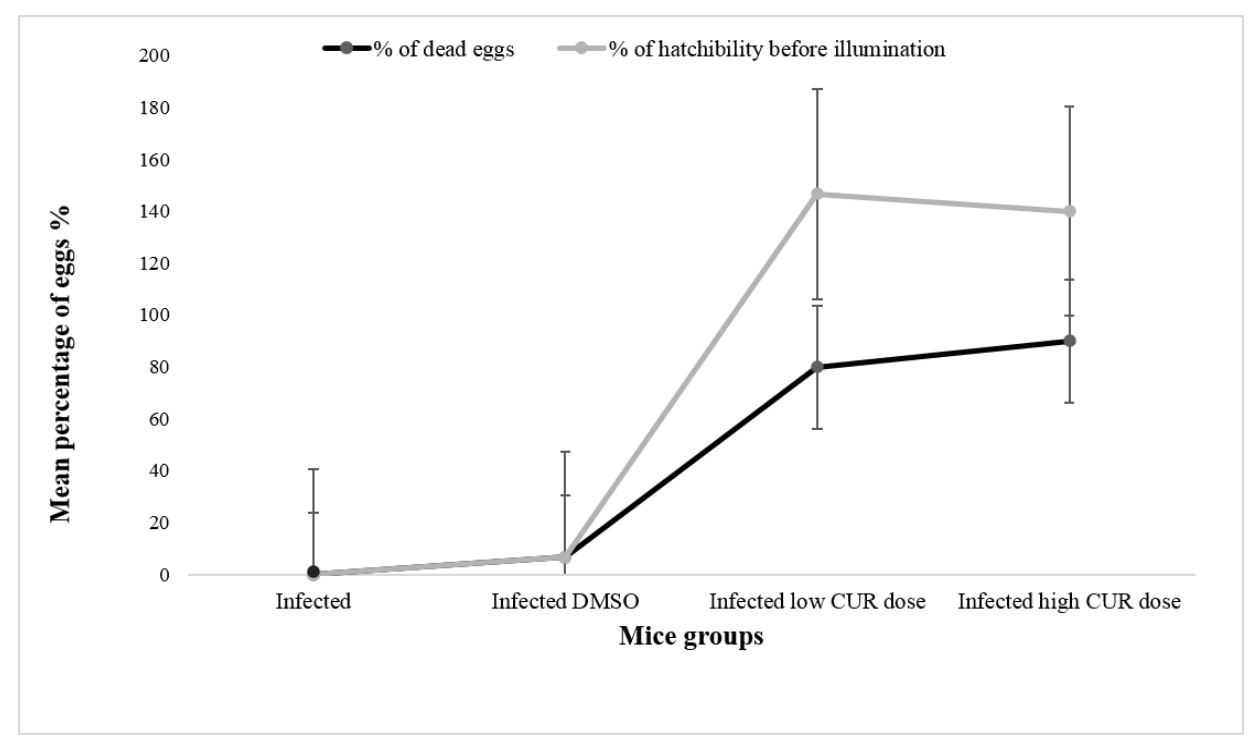

Figure 7. Effect of curcumin (CUR) administration on eggs' hatchability and viability percentage. The data are representative of two independent experiments. Eggs were obtained from Schistosoma mansoni infected mice and infected/treated with CUR at 0 (DMSO), low (20 mg/kg b.w.), and high ( $40 \mathrm{mg} / \mathrm{kg}$ b.w.) doses. The light line shows the percentage of miracidia released before exposure to illumination for $1 \mathrm{~h}$. The dark line shows mean percentage of eggs that failed to hatch (dead). Each point represents mean eggs percentage of five individual miceand vertical bars denote the standard deviation (SD) around the mean.

\section{Discussion}

Helminth infection has the ability to alter host metabolic products and immune functions along with modifying bacterial microbiota [29,30]. A loss of microbial diversity in the intestine was found in several human intestinal and extra-intestinal disorders [31]. Zhao et al. [4] suggested that in schistosomes' infection, egg granulomas in the intestine could influence the differentiation of the gut microbial community under pathophysiological conditions. In the current study, the interrelation between S. mansoni infection and the healthy intestinal microbial diversity was investigated and showed that the richness and diversity of intestinal microbiota of CD-1 mice had been changed after S. mansoni infection. This result is in agreement with the result of Su et al. [32], who observed significant alterations in gut microbiota of mice infected with helminth. Richness and diversity of intestinal microbiota in mice fecal samples had been changed after S. japonicum [4], and S. mansoni [11] infections when compared to uninfected controls. Another study on humans showed that $S$. haematobium infection is accompanied by diversity of gut microbiota, despite being bladder infecting schistosomes [33]. This observation is in contrast with Schneeberger et al. [34], who found that few or no modifications in microbiota phyla and diversity in humans infected with S. mansoni.

The intestinal content of $S$. mansoni infected mice in the current study was overabundant with the Enterobacteriaceae family (especially E. coli) followed by Staphylococcaceae, then Enterococcaceae, while Bacillaceae family was minimal in appearance. Enterobacteriaceae are one of the most abundant bacterial families found in inflammatory gut diseases, including chronic liver diseases [35]. E. coli are group of bacteria normally present in the intestinal tract; some are pathogenic, causing vomiting, 
stomach pain, and diarrhea [36]. On the other hand, gut microbiota in uninfected and S. japonicum infected mice were dominated by Firmicutes, Bacteroidetes, and Proteobacteria [34].

A neutral polyphenolic compound (CUR) has numerous pharmacological activities and therapeutic potential against many diseases $[37,38]$. Therapeutic benefits of CUR may result from either its regulative effect on gut microbiota [28] or its metabolic products released upon the action of gut microbiota [39]. Richness and diversity of microbiota were decreased by orally administered CUR in a non-alcoholic fatty liver disease (NAFLD) rat model [40]. Accordingly, the influence of orally-administeredCUR on the composition of gut microbiota of naive mice was investigated in the current study.

CUR administration led to high variation in the Enterobacteriaceae family including a significant increase in Pseudomonas sp. anda significant decrease in E. coli. This alteration was concentration-dependent. Similarly, both turmeric extract [41] and CUR [42] were found to significantly decrease the growth of E. coli, the most abundant bacteria in the intestinal tract. Oral administration of CUR significantly increased the number of bacterial species in gut microbiota of estrogen deficiency-induced rats, from these Pseudomonas sp. and Serratia [43]. However, the present study showed insignificant alterations in Staphylococcaceae, Enterococcaceae, and Bacillaceae families of gut-microbiota of CURtreated mice compared to naïve ones. Noticeably, a significant inhibition of Candida sp., one of the most frequent causes of fungal infection, was detected in CUR treated groups compared to control ones. The inhibitory effect of CUR on Candida sp. was also detected by Gow et al. [44]; however, this was in vitro. The antifungal CUR effect was explained by its effect on the composition of the lipid membrane that leads to reactive oxygen species (ROS) production causing early apoptosis [45] or its effect on cell wall integrity genes that leads to cell wall damage and membrane permeabilization [46].

The remarkable effects of CUR on isolated gut microbiota may explain the wide range of its beneficial effects. Several studies showed that CUR has positive effects on several diseases by changing the distribution of some gut microbiota $[27,28,47]$; however, schistosomiasis was not included. For the first time, the present study examined the isolated intestinal microbiota changes in S. mansoni-infected mice and their potential impact on treatment outcome based on oral CUR application. Interestingly, oral administration of high and low CUR doses induced alterations on the recovered gut microbiota of S. mansoni infected mice, similar to those that occurred in naïve mice, however in a more highly significant manner. This indicates that the dominance of Pseudomonas sp. is not linked with disease conditions. We suggest that CUR tends to increase Pseudomonas sp., while schistosomes tend to decrease it, in a dose-dependent manner. This may be explained by Breternitz et al. [48], who found that a cytotoxic protein (MW $28 \mathrm{kDa}$ ) from Pseudomonas aeruginosua can damage the surface membrane of an adult $S$. mansoni worm, in vitro, by forming membrane pores which are responsible for the breakdown of the permeability barrier. This may be an important mechanism underlying therapeutic benefits of CUR.

Anti-helminth host immunity is dependent on the microbiota [49]. Helminth infections-induced type 2 immune responses have the ability to modify host microbiota that benefit their survival $[50,51]$. Holzscheiter et al. [13] studied the relation between host's immune system and S. mansoni as well as microbiota; however, the involvement of CUR has never been addressed. The interaction of intestinal helminthes and bacterial microbes dampens or deceives host immunity to expand their survival. Where bacteria tend to suppress Th1/Th17 and helminthes tend to enhance Th2 mechanisms [52], interestingly, both of them tend to activate Treg [53]. Currently, CUR significantly increased IgM and $\operatorname{IgG}(\operatorname{IgG} 1>>\operatorname{IgG} 2 b)$ antibody production against egg-derived antigen (LAP) in the serum of mice infected with S. mansoni cercariae. This is in agreement with Allam [54], who found that CUR treatment augmented IgG and IgG1 responses against soluble egg antigens; however, insignificant changes in serum IgM and IgG2a serum levels of $S$. mansoni infected mice were also detected in his study.

The present study showed that $S$. mansoni infection failed to increase IL-4 (Th2) and IFN- $\gamma$ (Th1) serum levels while CUR treatment (high dose) significantly $(p<0.001, p<0.05$, respectively) increased IL-4 and IFN- $\gamma$. Accordingly, IL-4 and IFN- $\gamma$ did not show a significant relationship with schistosome infection status or intensity [51]. However, schistosome eggs' antigens (the major cause 
of chronic inflammation in the gut) induced Th2 immune responses (IL-13, IL-5, and IL-4) that suppressed the initial Th1 responses [7], and are responsible for several pathological outcomes [55]. Holzscheiter et al. [13] elucidated the requirement of host intestinal microbiota for schistosomes to initiate Th1 immunopathology. Based on that, Toxoplasma gondii required Gram-negative bacteria as E. coli in the initiation of intestinal Th1 immunopathology in mice [56]. In agreement with these studies S. mansoni infection increased E. coli in the gut microbiota of mice and CUR opposed this action. Several bacterial species have been linked with pathogenesis in humans, resulting in either a severe disease burden and/or death [57]. Another study found that CUR inhibited the growth of E. coli [41].

In the present study, CUR, especially at high doses, was able to induce protection against schistosomiasis, it significantly reduced worm burdens. Unlike other drugs, it affects adult male and female worms [54]. This may be due to its direct toxic effects such as those reported by Kiuchi et al. [58] and Araújo and Leon [59] on Toxocaracanis. Moreover, CUR, in our study, recorded a significant reduction (42.1\%) in small intestine egg load; however, it was insignificant in the liver (\%) at both low and high concentrations. As in previous studies, the impact of CUR on the microbiota of the intestine, not of the liver, might have a role in this reduction $[28,60]$. Furthermore, the impact of microbiota on CUR by reduction, demethylation, hydroxylation, and acetylation or the combination of these [61] may release metabolites that affect intestinal egg burdens. The antischistosomal and liver-protective effects of CUR compared with those of PZQ were also studied by [62] and revealed that murine schistosomiasis mansoni treated with CUR induced a positive effect by a reduction in worm and egg burdens.

In the current study, CUR treatment showed a significant effect on both immature and dead ova (39.4 and $72.9 \%$, respectively), and, on the contrary, an insignificant effect on mature ova (13.7\%) was obtained particularly in high CUR doses. Magalhães et al. [63] and Morais et al. [64] found that the significant decrease in the development of eggs produced by the adult $S$. mamsoni worms did not result from the separation of the coupled adult worms, but it may be related to the in vitro effect of CUR. This was explained by the inhibitory effect of CUR on the ubiquitin-proteasome system, subsequently, reduction in lung-stage schistosomula number, worm burden, and egg count was recorded [65]. Similar to the in vitro study done by [24], CUR was found to increase the hatchability and escape of premature miracidium and led to their death by affecting on the integrity of the shell wall of eggs at low and high concentrations. Pluta et al. [66] showed that the microflora is the way for the fulfillment gaps between poor bioavailability and the enormous effects of CUR on health.

In conclusion, intestinal inflammation due to schistosomiasis affects the intestinal barrier function, increasing bacterial translocation and affecting bacteria number and type. CURis able to offset the sequelae of intestinal barrier dysfunction through alteration in bacterial number, translocation, and inflammation. In addition, an immunomodulatory effect of CUR by increasing IgG and IgG1 antibodies and rising of IL-4 and IFN- $\gamma$ cytokines level against egg antigen led to a reduction in worm and intestinal egg burdens. Based on this evidence, CUR looks promising in the treatment of schistosomiasis. Additionally, the findings, taken together and with the article by Breternitz et al. [48], suggest a novel mechanism for CUR in vivo schistosomicidal activity.

\section{Materials and Methods}

\subsection{Curcumin}

CUR (1,7-bis (4-hydroxy-3-methoxyphenyl)-1,6-heptadiene-3,5-dione) powder was purchased from Sigma-Aldrich (St. Louis, MO, USA, Catalogue number: 08511). CUR was dissolved in $1 \%$ dimethyl sulfoxide (DMSO, Sigma-Aldrich) in RPMI 1640 medium (Lonza, Basel, Switzerland) supplemented with $5 \%$ fetal calf serum (FCS). 


\subsection{Animals}

Female healthy Swiss albino CD-1 mice, weighing $20 \pm 5 \mathrm{~g}$ were purchased from the Schistosome Biological Supply Program, Theodore Bilharz Research Institute (SBSP/TBRI), Giza, Egypt and then housed in the animal facility of the Zoology Department, Faculty of Science, Cairo University. The mice were kept under aseptic conditions, fed a standard chow diet, and provided with pure water.

\subsection{Ethical Consideration}

The experiments were approved by the Institutional Animal Care and Use Committee (IACUC) of the Faculty of Science, Cairo University, Egypt, with number CU///F/57/19. All the experimental procedures were carried out in accordance with international guidelines for the care and use of laboratory animals performed following the recommendations of the current edition of the Guide for the Care and Use of Laboratory Animals, Institute of Laboratory Animal Resources, National Research Council, USA.

\subsection{Experimental Design}

Experiment 1 was devised to investigate the impact of $S$. mansoni infection on the composition of gut microbiota. Female, 6-week-old CD-1 mice were randomly distributed into two main groups of 4 mice each, $S$. mansoni infected and entirely naïve groups. The mice infection was percutaneous with 100 Egyptian strain of $S$. mansoni cercariae (SBSP/TBRI) per each immediately after shedding from Biomphalaria alexandrina as described previously [67]. Examination of microbiota in small and large intestine was performed at eight weeks post infection.

Experiment 2 was conducted to assess the influence of curcumin on the composition of mouse microbiota. A total of 20 female, 6-week-old CD-1 mice were divided into 4 groups ( 5 mice/each). The first group was left intact, and the others were orally given $1.0 \mathrm{~mL} / \mathrm{mouse}$ of RPMI medium supplemented with $1 \%$ DMSO containing 0 (DMSO controls), 20 (low) and 40 (high) $\mathrm{mg} / \mathrm{kg}$ b.w. CUR doses. Treatment was given orally three times, with two day intervals. These mice were assayed for the effect of CUR on the intestinal microbiota one week after the last oral injection.

Experiment 3 was performed to examine the interaction of schistosomes, CUR, and microbiota. A total of 20 female, 6-week-old CD-1 mice were percutaneously exposed to $100 \mathrm{~S}$. mansoni cercariae, and randomly distributed into 4 equal groups. The first group was left infected and untreated. The remaining S. mansoni-infected mice groups were orally administered with $1.0 \mathrm{~mL} /$ mouse RPMI medium supplemented with 1\% DMSO containing 0 (infected DMSO controls), 20 (infected low), and 40 (infected high) $\mathrm{mg} / \mathrm{kg}$ b.w. CUR doses starting 6 weeks post infection. In parallel, a group of mice $(n=5)$ was uninfected and untreated and considered as naïve. The mice infection was percutaneous with $100 \mathrm{~S}$. mansoni cercariae per each. Treatment was given orally three times, with two day intervals. Mice were assessed for the composition of gut microbiota, serum antibody and cytokine immune responses, and parasitological parameters at one week after the last oral injection, i.e., 8 weeks post S. mansoni infection.

\subsection{Bleeding and Sample Collection}

One-week post CUR treatment and about 8 weeks post-infection, blood samples were collected from each mouse (via tail) and sera were separated and kept in aliquots at $-20{ }^{\circ} \mathrm{C}$ until used (for immunological assay). After that, mice were euthanized with an intraperitoneal injection of $5 \mathrm{mg} / \mathrm{kg}$ thiopental sodium (EPICO, 10th of Ramadan City, Egypt) for perfusion and removal of liver and intestine (for microbiological and parasitological assays).

\subsection{Microbiological Parameters}

Small and large intestinal contents (mucus and feces) were collected and diluted (0, 1:10, 1:100, and 1:1000) in deionized sterile water. Then, a calibrated $10 \mu \mathrm{L}$ of each dilution was inoculated in Nutrient agar (HIMEDIA company REF: M001-500G, LOTNo.0000321511, India) with 5-10\% aseptically 
defibrinated sheep blood and MacConkey agar (OXOID CM0115 No.3-500G, LOT No. 2518594, UK) with Quadrant streaking method [68]. Bacteria were cultured at $37^{\circ} \mathrm{C}$ and examined after 24 and $48 \mathrm{~h}$ (h) for grown colony count of organisms. Gram stain (EDM, Egypt) was used to differentiate bacteria morphologically, by $40 \times$ light microscopy, followed by biochemical reactions [69].

Nine different biochemical reactions were used for identifying the type of organisms. A catalase test was used for differentiating Staphylococcus $s p$. that produced catalase enzyme using $3 \%$ hydrogen peroxide $\left(\mathrm{H}_{2} \mathrm{O}_{2}\right)$ [70]. A coagulase test was used to identify Staphylococcus aureus, which produces the coagulase enzyme [71]. A deoxyribonuclease (DNA-ase) test (HIMEDIA company REF: M482-500G, LOTNo.0000408977) was used to identify Serratia marcescens which produces DNA-ase enzyme [72]. A Bile Esculin hydrolysis test (OXOID CM0888-500G, LOT No. 1602186) was used as confirmatory test for Enterococcus sp. [73]. An oxidase test (Cytochrome oxidase test) (HIMEDIA Company) was used to identify the enzyme cytochrome oxidase which produced from bacteria especially Pseudomonas sp. [74]. A Motility Indole Ornithine test (HIMEDIA company REF: M378-500G, LOTNo.0000291389) was used to detect the bacteria which produce indole as E. coli, Citrobacter $s p$., and ornithine-decarboxylase activity of enteric Bacilli [75]. A Citrate Utilization test (OXOID company CM0155-500G, LOT No. 1740963) was used for detecting the ability of an organism to use citrate as its only source of carbon as in Citrobacter sp., Klebsiella sp., Serratia sp., and Proteus sp. [76]. A urease test (OXOID company CM0053-500G, LOT No. 1694661) was used to detect which type has the ability to produce urease enzyme such as Proteus sp. and Klebsiella sp. [77]. A triple sugar iron (TSI) (OXOID company CM0277-500G, LOT No. 1948263) detects the ability of the fermentation of microorganisms as in E. coli, Klebsiella sp. and Enterobacter sp. [78].

The developing colonies were counted through colony forming unit $/ \mathrm{mL}(\mathrm{CFU} / \mathrm{mL})$ and the relative density (R.D\%) of each microorganism was calculated as percentage of the total microorganisms count.

\subsection{Immunological Parameters}

\subsubsection{Antibody Assay}

Control and test mice serum antibody levels and isotypes were assessed on an individual mouse basis for binding to egg-derived antigens, namely leucine aminopeptidase in a recombinant form (rLAP, gift of Professor Dr. John P. Dalton, Queen University at Belfast, Northern Ireland) by indirect ELISA as described by Engvall and Perlmann [79] with some modifications.

For the antibody level, wells of polystyrene plates (Costar, Corning, NY, USA) were coated with $250 \mathrm{ng} /$ well rLAP in $100 \mu \mathrm{L}$ coating buffer (0.1 M Carbonate/bicarbonate buffer, $\mathrm{pH}$ 9.6) and incubated overnight at $4{ }^{\circ} \mathrm{C}$. Non-specific sites were blocked with $200 \mu \mathrm{L} /$ well of blocking buffer $(1 \%$ bovine serum albumin (BSA, Sigma) in D-PBS) for $1 \mathrm{~h}$. After incubation, all wells were washed 4 times with washing buffer PBS-T (phosphate buffer saline with $0.05 \%$ Tween-20). After washing, $100 \mu \mathrm{L} /$ well of serially dilute serum samples from 1:200 to 1:6400 in diluting buffer (PBS-T and 0.1\% BSA) were added in duplicate and incubated at room temperature for $1 \mathrm{~h}$. Hundred $\mu \mathrm{L} /$ well horseradish peroxidase (HRP)-labeled goat anti-mouse IgG (H + L) conjugate (1:5000 dilution) (KPL, Kirkegaard and Perry Laboratories, Inc., Gaithersburg, MD, USA) was added after washing and incubated for $1 \mathrm{~h}$. The color developed after adding $100 \mu \mathrm{L}$ of SureBlue TMB liquid substrate (Sigma) to each well and incubated for $30 \mathrm{~min}$. Reactivity was estimated spectrophotometrically at $650 \mathrm{~nm}$ by using an ELISA microplate reader (MultisKan EX, Labsystems, Helsinki, Finland).

For isotyping, mice serum samples were diluted to 1:500 for assessing Ig isotypesIgM, IgG2a, and 1:50 for IgG1, IgG2b, IgA, and IgE levels against rLAP. Biotin-labeled rat monoclonal antibody to mouse IgG1, IgG2b (Pharmingen, San Diego, CA, USA), IgA, and IgE (BioLegend, San Diego, CA, USA), was diluted into 1:500 in washing buffer. Monoclonal antibody to IgM and IgG2a (Pharmingen) labeled with AKP (alkaline phosphatase) was diluted into 1:3000 and 1:1000, respectively. $100 \mu \mathrm{L} /$ well of each conjugate was added for $1 \mathrm{~h}$ at room temperature, and then washed 3 times with $10 \mathrm{mM}$ Tris $(10 \mathrm{mM}$ Tris/ $\mathrm{HCl}, \mathrm{pH} 7.8+150 \mathrm{mMNaCl}$ ). Hundred $\mu \mathrm{L}$ of AKP-labeled streptavidin (Promega, 
Madison, WI, USA) was added to biotin-labeled conjugate wells. While $100 \mu \mathrm{L} /$ well of paranitrophenyl phosphate liquid substrate (Cal Biochemical, Jolly, Coa) was added to AKP conjugate wells. The plates were covered and incubated for $30 \mathrm{~min}$. at $37^{\circ} \mathrm{C}$. The reactivity was estimated spectrophotometrically at $405 \mathrm{~nm}$.

\subsubsection{Cytokines Assay}

Level of IFN- $\gamma$ and IL-4 cytokines was evaluated using sandwich ELISA kits (BioLegend) according to manufacturer's instruction.

The precoated microwell strips with anti-mouse IFN- $\gamma$ and IL- 4 antibodies were washed with $400 \mu \mathrm{L} /$ well washing buffer for 2 times before use. All wells were dried and incubated with $100 \mu \mathrm{L} /$ well of serially diluted standard or sera sample in sample diluents in duplicate. Fifty $\mu \mathrm{L} /$ well of biotin-conjugate (1:100 dilution in assay buffer) was added to all wells, sealed and incubated for $2 \mathrm{~h}$ at room temperature. Wells were washed 3 times, and then $100 \mu \mathrm{L} /$ well Streptavidin-HRP conjugate (1:100 dilution in assay buffer) was added to all wells and incubated for $1 \mathrm{~h}$. After washing 3 times, $100 \mu \mathrm{L}$ of SureBlue TMB substrate solution was added to each well. The reaction was stopped after $30 \mathrm{~min}$ by adding $100 \mu \mathrm{L} /$ well stop solution. The reactivity was estimated spectrophotometrically at $450 \mathrm{~nm}$. The cytokine concentration was obtained from the standard curve and expressed as $\mathrm{pg} / \mathrm{mL}$.

\subsection{Parasitological Parameters}

\subsubsection{Worm Burden}

Adult S. mansoni worms were recovered from on an individual mouse basis by perfusion of the hepatic portal venous system and mesenteric blood vessels 8 weeks after cercarial exposure and 7 days after last CUR treatment as described [80]. The number of males, females, and couples were counted.

\subsubsection{Oogram Map}

After mice perfusion, small intestinal fragment of about $1 \mathrm{~cm}$ was cut longitudinally, rinsed in saline, slightly dried on filter paper, compressed between two glass slides, and examined under a microscope for immature, mature, and dead egg types [81].

\subsubsection{Total Egg Counts}

Hundred mg pieces of liver and small intestine were evaluated for egg burden following digestion with $4 \%$ potassium hydroxide $(\mathrm{KOH})$ digestion for $2 \mathrm{~h}$ at $37^{\circ} \mathrm{C}$ in water bath with shaking. The number of eggs/g tissue was estimated on an individual mouse basis in pellets obtained after centrifugation and then resuspended in $2 \%$ of $\mathrm{NaCl}$ in accordance with the total organ weight [80].

\subsubsection{Egg Hatchability}

S. mansoni eggs were retrieved following liver and small intestine tissue digestion in collagenase B (Sigma) according to Dalton et al. [82] with some modifications. Five hundred milligrams liver and small intestine of each CUR untreated or treated S. mansoni infected mouse were homogenized and the homogenate then suspended in Hank's buffer deionized and incubated $3 \mathrm{~h}$ with shaking in the presence ofcollagenase B $(0.05 \%, w / v)$. The mixture was sieved, and the filtrate was applied to the top of a Percoll (Pharmacia, Uppsala, Sweden) in 0.25 M sucrose (Sigma). After centrifugation, the pellet (schistosome eggs) was suspended in 1\% normal saline for egg count. Then the suspension was centrifuged, and the pellet was added to $5 \mathrm{~mL}$ water and exposed to a bright light. The supernatant was removed after $30 \mathrm{~min}$ for observing the viability of hatched miracidia then drop of iodine was added for miracidia count. 


\subsection{Statistical Analysis}

All data values were tested for normality. The SPSS 20.0 software (SPSS, Chicago, IL, USA) was used in determination of standard deviation (SD) and unpaired Student's-t-2-tailed test was used to analyze the statistical significance of differences between selected values and considered significant at $p<0.05$.

Author Contributions: Conceptualization, N.M. and M.A.E.D.; methodology, A.A., M.A.E.D., M.A.E.-G. and N.M.; software, N.M.; validation, M.A.E.D. and M.A.E.-G.; formal analysis, A.A.; investigation, A.A., M.A.E.D. and M.A.E.-G.; resources, N.M.; data curation, M.A.E.D. and M.A.E.-G.; writing-original draft preparation, N.M.; writing-review and editing, M.A.E.D., M.A.E.-G. and N.M.; visualization, A.A., M.A.E.D. and M.A.E.-G.; supervision, N.M., M.A.E.D. and M.A.E.-G.; project administration, N.M. All authors have read and agreed to the published version of the manuscript.

Funding: This research was funded by Cairo University project, grant 29 to N.M.

Acknowledgments: Financial support by Cairo University Giza, Egypt; grant 29 is gratefully acknowledged.

Conflicts of Interest: The authors declare no conflict of interest. The funders had no role in the design of the study; in the collection, analyses, or interpretation of data; in the writing of the manuscript, or in the decision to publish the results.

\section{References}

1. Berrilli, F.; Di Cave, D.; Cavallero, S.; D'Amelio, S. Interactions between parasites and microbial communities in the human gut. Front. Cell Infect. Microbiol. 2012, 2, 141. [CrossRef] [PubMed]

2. Hotez, P.J.; Brindley, P.J.; Bethony, J.M.; King, C.H.; Edward, J.; Pearce, E.J.; Jacobson, J. Helminth infections: The great neglected tropical diseases. J. Clin. Investig. 2008, 118, 1311-1321. [CrossRef] [PubMed]

3. McManus, D.P.; Dunne, D.W.; Sacko, M.; Utzinger, J.; Vennervald, B.J.; Zhou, X.N. Schistosomiasis. Nat. Rev. Dis. 2018, 4, 13. [CrossRef] [PubMed]

4. Zhao, Y.; Yang, S.; Li, B.; Li, W.; Wang, J.; Chen, Z.; Yang, J.; Tan, H.; Li, J. Alterations of the Mice Gut Microbiome via Schistosoma japonicum Ova-Induced Granuloma. Front. Microbiol. 2019, 10, 352. [CrossRef]

5. Van der Werf, M.J.; de Vlas, S.J.; Brooker, S.; Looman, C.W.; Nagelkerke, N.J.; Habbema, J.D.; Engels, D. Quantification of clinical morbidity associated with schistosome infection in sub-Saharan Africa. Acta Trop. 2003, 86, 125-139. [CrossRef]

6. Gryseels, B.; Polman, K.; Clerinx, J.; Kestens, L. Human schistosomiasis. Lancet 2006, 368, $1106-1118$. [CrossRef]

7. Wilson, M.S.; Mentink-Kane, M.M.; Pesce, J.T.; Ramalingam, T.R.; Thompson, R.; Wynn, T.A. Immunopathology of schistosomiasis. Immunol. Cell Biol. 2007, 85, 148-154. [CrossRef]

8. Schwartz, C.; Fallon, P.G. Schistosoma "eggs-itching" the host: Granuloma formation and egg excretion. Front. Immunol. 2018, 9, 2492. [CrossRef]

9. Pearce, E.J.; MacDonald, A.S. The immunobiology of schistosomiasis. Nat. Rev. Immunol. 2002, 2, 499-511. [CrossRef]

10. Layland, L.E.; Mages, J.; Loddenkemper, C.; Hoerauf, A.; Wagner, H.; Lang, R.; da Costa, C.U. Pronounced phenotype in activated regulatory T cells during a chronic helminth infection. J. Immunol. 2010, 184, 713-724. [CrossRef]

11. Jenkins, T.P.; Peachey, L.E.; Ajami, N.J.; MacDonald, A.S.; Hsieh, M.H.; Brindley, P.J.; Cantacessi, C.; Rinaldi, G. Schistosoma mansoni infection is associated with quantitative and qualitative modifications of the mammalian intestinal microbiota. Sci. Rep. 2018, 8, 12072. [CrossRef] [PubMed]

12. Thursby, E.; Juge, N. Introduction to the human gut Microbiota. Biochem. J. 2017, 474, 1823-1836. [CrossRef]

13. Holzscheiter, M.; Layland, L.E.; Loffredo-verde, E. Lack of host gut Microbiota alters immune responses and intestinal granuloma formation during schistosomiasis. Clin. Exp. Immunol. 2013, 175, 246-257. [CrossRef]

14. Vuong, H.E.; Yano, J.M.; Fung, T.C.; Hsiao, E.Y. The microbiome and host behavior. Annu. Rev. Neurosci. 2017, 40, 21-49. [CrossRef] [PubMed]

15. Spor, A.; Koren, O.; Ley, R. Unravelling the effects of the environment and host genotype on the gut microbiome. Nat. Rev. Microbiol. 2011, 9, 279-290. [CrossRef] [PubMed] 
16. Carding, S.; Verbeke, K.; Vipond, D.T.; Corfe, B.M.; Owen, L.J. Dysbiosis of the gut microbiota in disease. Microb. Ecol. Health Dis. 2015, 26, 26191. [CrossRef]

17. Ubeda, C.; Djukovic, A.; Isaac, S. Roles of the intestinal microbiota in pathogen protection. Clin. Transl. Immunol. 2017, 6, e128. [CrossRef] [PubMed]

18. Doenhoff, M.J.; Cioli, D.; Utzinger, J. Praziquantel: Mechanisms of action, resistance and new derivatives for schistosomiasis. Curr. Opin. Infect. Dis. 2008, 21, 659-667. [CrossRef] [PubMed]

19. Kayser, O.; Kiderlen, A.F.; Croft, S.L. Natural products as antiparasitic drugs. Parasitol. Res. 2003, 90, S55-S62. [CrossRef] [PubMed]

20. de Melo, N.I.; Magalhães, L.G.; Carvalho, C.E.; Wakabayashi, K.A.L.; Aguiar, G.P.; Ramos, R.C.; Mantovani, A.L.L.; Turatti, I.C.C.; Rodrigues, V.; Groppo, M.; et al. Schistosomicidal activity of the essential oil of Ageratum conyzoides L. (Asteraceae) against Schistosoma mansoni adult worms. Molecules 2011, 16, 762-773. [CrossRef] [PubMed]

21. Heger, M.; van Golen, R.F.; Broekgaarden, M.; Michel, M.C. The molecular basis for the pharmacokinetics and pharmacodynamics of curcumin and its metabolites in relation to cancer. Pharmacol. Rev. 2013, 66, 222-307. [CrossRef] [PubMed]

22. Sreedhar, R.; Arumugam, S.; Thandavarayan, R.A.; Karuppagounder, V.; Watanabe, K. Curcumin as a therapeutic agent in the chemoprevention of inflammatory bowel disease. Drug Discov. Today. 2016, 21, 843-849. [CrossRef] [PubMed]

23. Haddad, M.; Sauvain, M.; Deharo, E. Curcuma as a parasiticidal agent: A review. Planta Med. 2011, 77, 672-678. [CrossRef] [PubMed]

24. Abou El Dahab, M.M.; Shahat, S.M.; Mahmoud, S.S.M.; Mahana, N.A. In vitro effect of curcumin on Schistosoma species viability, tegument ultrastructure and egg hatchability. Exp. Parasitol. 2019, 199, 1-8. [CrossRef] [PubMed]

25. Metzler, M.; Pfeiffer, E.; Schulz, S.I.; Dempe, J.S. Curcumin Uptake and Metabolism. Biofactors 2013, 39, 14-20. [CrossRef] [PubMed]

26. Nelson, K.M.; Dahlin, J.L.; Bisson, J.; Graham, J.; Pauli, G.F.; Walters, M.A. The essential medicinal chemistry of curcumin. J. Med. Chem. 2017, 60, 1620-1637. [CrossRef]

27. Di Meo, F.; Margarucci, S.; Galderisi, U.; Crispi, S.; Peluso, G. Curcumin, Gut Microbiota, and Neuroprotection. Nutrients 2019, 11, 2426. [CrossRef]

28. Shen, L.; Liu, L.; Ji, H.F. Regulative effects of curcumin spice administration on gut microbiota and its pharmacological implications. Food Nutr. Res. 2017, 61, 1361780. [CrossRef]

29. Grencis, R.K. Immunity to helminths: Resistance, regulation, and susceptibility to gastrointestinal nematodes. Ann. Rev. Immunol. 2015, 33, 201-225. [CrossRef]

30. Floudas, A.; Aviello, G.; Schwartz, C.; Jeffery, L.B.; O’Toole, P.W.; Fallon, P.G. Schistosoma mansoni worm infection regulates the Intestinal microbiota and susceptibility to colitis. Infect. Immun. 2019, 87, e00275-19. [CrossRef]

31. Tilg, H.; Adolph, T.E.; Gerner, R.R.; Moschen, A.R. The intestinal microbiota in colorectal cancer. Cancer Cell 2018, 33, 954-964. [CrossRef] [PubMed]

32. Su, C.; Su, L.; Li, Y.; Long, S.R.; Chang, J.; Zhang, W.; Walker, W.A.; Xavier, R.J.; Cheravil, B.J.; Shi, H.N. Helminth induced alterations of the gut microbiota exacerbate bacterial colitis. Mucosal Immunol. 2018, 11, 144-157. [CrossRef] [PubMed]

33. Kay, G.L.; Millard, A.; Sergeant, M.J.; Midzi, N.; Gwisai, R.; Mduluza, T.; Jvens, A.; Nausch, N.; Mutapi, F.; Pallen, M. Differences in the faecal microbiome in Schistosoma haematobium infected children vs uninfected children. PLoS Negl. Trop. Dis. 2015, 9, e0003861. [CrossRef]

34. Schneeberger, P.H.; Coulibaly, J.T.; Panic, G.; Daubenberger, C.; Gueuning, M.; Frey, J.; Frey, J.E.; Keiser, J. Investigations on the interplays between Schistosoma mansoni, praziquantel and the gut microbiome. Parasites Vectors. 2018, 11, 168. [CrossRef] [PubMed]

35. Zeng, M.; Inohara, N.; Nuñez, G. Mechanisms of inflammation driven bacterial dysbiosis in the gut. Mucosal Immunol. 2017, 10, 18-26. [CrossRef]

36. Kaper, J.B.; Nataro, J.P.; Mobley, H.L. Pathogenic Escherichia coli. Nat. Rev. Microbiol. 2004, 2, $123-140$. [CrossRef]

37. Gupta, S.C.; Prasad, S.; Kim, J.H.; Patchva, S.; Webb, L.J.; Priyadarsini, I.K.; Aggarwal, B.B. Multitargeting by curcumin as revealed by molecular interaction studies. Nat. Prod. Rep. 2011, 28, 1937-1955. [CrossRef] 
38. Gupta, S.C.; Patchva, S.; Aggarwal, B.B. Therapeutic roles of curcumin: Lessons learned from clinical trials. AAPS J. 2013, 15, 195-218. [CrossRef]

39. Hassaninasab, A.; Hashimoto, Y.; Tomita-Yokotani, K.; Kobayashi, M. Discovery of the curcumin metabolic pathway involving a unique enzyme in an intestinal microorganism. Proc. Natl. Acad. Sci. USA 2011, 108, 6615-6620. [CrossRef]

40. Feng, W.; Wang, H.; Zhang, P.; Gao, C.; Tao, J.; Ge, Z.; Zhu, D.; Bi, Y. Modulation of gut microbiota contributes to curcumin-mediated attenuation of hepatic steatosis in rats. Biochim. Biophys. Acta 2017, 1861, 1801-1812. [CrossRef]

41. Gul, P.; Bakht, J. Antimicrobial activity of turmeric extract and its potential use in food industry. J. Food Sci. Technol. 2015, 52, 2272-2279. [CrossRef] [PubMed]

42. Yun, D.G.; Lee, D.G. Antibacterial activity of curcumin via apoptosis like response in Escherichia coli. Appl. Microbiol. Biotechnol. 2016, 100, 5505-5514. [CrossRef] [PubMed]

43. Zhang, Z.; Chen, Y.; Xiang, L.; Wang, Z.; Xiao, G.G.; Hu, J. Effect of curcumin on the diversity of gut microbiota in ovariectomized rats. Nutrients 2017, 9, 1146. [CrossRef] [PubMed]

44. Gow, N.A.; van de Veerdonk, F.L.; Brown, A.J.; Netea, M.G. Candida albicans morphogenesis and host defence: Discriminating invasion from colonization. Nat. Rev. Microbiol. 2011, 10, 112-122. [CrossRef] [PubMed]

45. Sharma, M.; Dhamgaye, S.; Singh, A.; Prasad, R. Lipidome analysis reveals antifungal polyphenol curcumin affects membrane lipid homeostasis. Front. Biosci. 2012, 4, 1195-1209. [CrossRef]

46. Kumar, A.; Dhamgaye, S.; Maurya, I.K.; Singh, A.; Sharma, M.; Prasad, R. Curcumin targets cell wall integrity via calcineurin-mediated signaling in Candida albicans. Antimicrob. Agents Chemother. 2014, 58, 167-175. [CrossRef]

47. Cotillard, A.; Kennedy, S.P.; Kong, L.C.; Prifti, E.; Pons, N.; Le Chatelier, E.; Almeida, M.; Quinquis, B.; Levenez, F.; Galleron, N.; et al. Dietary intervention impact on gut microbial gene richness. Nature 2013, 500, 585-588. [CrossRef]

48. Breternitz, R.; Kusel, J.R.; Lutz, F.; Buehrle, C.; Ruppel, A. Schistosoma mansoni: Stage-dependent formation and repair of membrane pores induced by a cytotoxin from Pseudomonas aeruginosa. Exp. Parasitol. 1992, 74, 340-347. [CrossRef]

49. Entwistle, L.J.; Pelly, V.S.; Coomes, S.M.; Kannan, Y.; Perez-Lloret, J.; Czieso, S.; Silva Dos Santos, M.; MacRae, J.I.; Collinson, L.; Sesay, A.; et al. Epithelial-cell-derived phospholipase A 2 group 1B is an endogenous anthelmintic. Cell Host Microbe 2017, 22, 484-493. [CrossRef]

50. Brestoff, J.R.; Artis, D. Immune regulation of metabolic homeostasis in health and disease. Cell 2015, 161, 146-160. [CrossRef]

51. Mutapi, F.; Winborn, G.; Midzi, N.; Taylor, M.; Mduluza, T.; Maizels, R.M. Cytokine responses to Schistosoma haematobium in a Zimbabwean population: Contrasting profiles for IFN-gamma, IL-4, IL-5 and IL-10 with age. BMC Infect. Dis. 2007, 7, 139. [CrossRef] [PubMed]

52. Reynolds, L.A.; Finlay, B.B.; Maizels, R.M. Cohabitation in the intestine: Interactions among helminth parasites, bacterial microbiota, and host immunity. J. Immunol. 2015, 195, 4059-4066. [CrossRef] [PubMed]

53. Maizels, R.M.; Smith, K.A. Regulatory T cells in infection. Adv. Immunol. 2011, 112, 73-136. [PubMed]

54. Allam, G. Immunomodulatory effects of curcumin treatment on murine schistosomiasis mansoni. Immunobiology 2009, 214, 712-727. [CrossRef]

55. Fallon, P.G.; Richardson, E.J.; McKenzie, G.J.; McKenzie, A.N. Schistosome infection of transgenic mice defines distinct and contrasting pathogenic roles for IL-4 and IL-13: IL-13 is a profibrotic agent. J. Immunol. 2000, 164, 2585-2591. [CrossRef]

56. Heimesaat, M.M.; Bereswill, S.; Fischer, A.; Fuchs, D.; Struck, D.; Niebergall, J.; Jahn, H.-K.; Dunay, I.R.; Moter, A.; Gescher, D.M.; et al. Gram-negative bacteria aggravate murine small intestinal Th1-type immunopathology following oral infection with Toxoplasma gondii. J. Immunol. 2006, 177, 8785-8795. [CrossRef]

57. Shin, N.-R.; Whon, T.W.; Bae, J.-W. Proteobacteria: Microbial signature of dysbiosis in gut microbiota. Trends Biotechnol. 2015, 33, 496-503. [CrossRef]

58. Kiuchi, F.; Goto, Y.; Sugimoto, N.; Akao, N.; Kondo, K.; Tsuda, Y. Nematocidal activity of turmeric, synergistic action of curcuminoids. Chem. Pharm. Bull. 1993, 41, 1640-1643. [CrossRef]

59. Araújo, C.A.C.; Leon, L.L. Biological activities of Curcuma longa L. Mem. Inst. Oswaldo Cruz. 2001, 96, 723-728. [CrossRef] 
60. Zam, W. Gut microbiota as a prospective therapeutic target for curcumin: A review of mutual influence. J. Nutr. Metab. 2018, 2018, 1367984. [CrossRef]

61. Lou, Y.; Zheng, J.; Hu, H.; Lee, J.; Zeng, S. Application of ultraperformance liquid chromatography coupled with quadrupole time-of-flight mass spectrometry to identify curcumin metabolites produced by human intestinal bacteria. J. Chromatogr. B Analyt. Technol. Biomed. Life Sci. 2015, 985, 38-47. [CrossRef] [PubMed]

62. El-Ansary, A.; Ahmed, S.; Aly, S. Antischistosomal and liver protective effects of Curcuma longa extract in Schistosoma mansoni infected mice. Indian J. Expt. Biol. 2007, 45, 791-801.

63. Magalhães, L.G.; Machado, C.B.; Morais, E.R.; Moreira, E.B.; Soares, C.S.; da Silva, S.H.; Filho, A.A.; Rodrigues, V. In vitro schistosomicidal activity of curcumin against Schistosoma mansoni adult worms. Parasitol. Res. 2009, 104, 1197-1201. [CrossRef] [PubMed]

64. Morais, E.R.; Oliveira, K.C.; Magalhães, L.G.; Moreira, E.B.; Verjovski Almeida, S.; Rodrigues, V. Effects of curcumin on the parasite Schistosoma mansoni: A transcriptomic approach. Mol. Biochem. Parasitol. 2013, 187, 91-97. [CrossRef]

65. Guerra-Sá, R.; Castro-Borges, W.; Evangelista, E.A.; Kettelhut, I.C.; Rodrigues, V. Schistosoma mansoni: Functional proteasomes are required for development in the vertebrate host. Exp. Parasitol. 2005, 109, 228-236. [CrossRef]

66. Pluta, R.; Januszewski, S.; Ułamek-Kozioł, M. Mutual two-way interactions of curcumin and gut microbiota. Int. J. Mol. Sci. 2020, 21, 1055. [CrossRef]

67. Tucker, M.S.; Karunaratne, L.B.; Lewis, F.A.; Freitas, T.C.; Liang, Y.S. Schistosomiasis. Curr. Protoc. Immunol. 2013, 103, 19.1.1-19.1.58. [CrossRef]

68. Sanders, E.R. Aseptic laboratory technique: Plating methods. J. Vis. Exp. 2012, 63, e3064. [CrossRef]

69. Bhattacharyya, S.; Prasad, A.; Sarfraz, A.; Jaiswal, N.K.; Kumar, R. Evaluation of a new method for Gram staining of bacteria. Med. Sci. 2015, 18, 16-17.

70. Mahon, C.R.; Lehman, D.C.; Manuselis, G. Textbook of Diagnostic Microbiology, 4th ed.; Saunders: Philadelphia, PA, USA, 2011.

71. McDonald, C.L.; Chapin, K. Rapid identification of Staphylococcus aureus from blood culture bottles by a classic 2-hour tube coagulase test. J. Clin. Microbiol. 1995, 33, 50-52. [CrossRef]

72. Jorgensen, J.H.; Pfaller, M.A.; Carroll, K.C.; Funke, G.; Landry, M.L.; Richter, S.S.; Warnock, D.W. Manual of Clinical Microbiology, 11th ed.; ASM Press: Washington, DC, USA, 2015.

73. Chan, P.C.K.; Porschen, R.K. Evaluation of Kanamycin-Esculin Bile Agar for Isolation and Presumptive Identification of Bacteroides fragilis Group. J. Clin. Microbiol. 1977, 6, 528-529. [PubMed]

74. Gaby, W.L.; Hadley, C. Practical laboratory test for the identification of Pseudomonas aeruginosa. J. Bacteriol. 1957, 74, 356-358. [CrossRef] [PubMed]

75. Ederer, G.M.; Clark, M. Motility-indoleornithine medium. Appl. Microbiol. 1970, 20, 849-850. [CrossRef] [PubMed]

76. Ewing, W.H.; Edwards, P.R. The principal divisions and groups of Enterobacteriaceae and their differentiation. Intern. Bull. Bacteriol. Nomen. Taxon. 1960, 10,1-12. [CrossRef]

77. Christensen, W.B. Urea Decomposition as a Means of Differentiating Proteus and Paracolon Cultures from Each Other and from Salmonella and Shigella Types. J. Bacteriol. 1946, 52, 461-466. [CrossRef]

78. Edwards, P.R.; Ewing, W.H. Identification of Enterobacteriacea, 3rd ed.; Burgess Publishing Co.: Minneapolis, MN, USA, 1972; pp. 351-352.

79. Engvall, E.; Perlmann, P. Enzyme-linked immunosorbent assay (ELISA). Quantitative assay of immunoglobulin G. Immunochemistry 1971, 8, 871-874. [CrossRef]

80. Tallima, H.; Montash, M.; Veprek, P.; Velek, J.; Jezek, J.; El Ridi, R. Differences in immunogenicity and vaccine potential of peptides from Schistosoma mansoni glyceraldehyde 3-phosphate dehydrogenase. Vaccine 2003, 21, 3290-4300. [CrossRef] 
81. Pellegrino, J.; Faria, J. The oogram method for the screening of drugs in schistosomiasis mansoni. Am. J. Trop. Med. Hyg. 1965, 14, 363-369. [CrossRef]

82. Dalton, J.P.; Day, S.R.; Drew, A.C.; Brindley, P.J. A method for the isolation of schistosome eggs and miracidia free of contaminating host tissues. Parasitology 1997, 115, 29-32. [CrossRef]

(C) 2020 by the authors. Licensee MDPI, Basel, Switzerland. This article is an open access article distributed under the terms and conditions of the Creative Commons Attribution (CC BY) license (http://creativecommons.org/licenses/by/4.0/). 